\title{
SOVEREIGN DEBT RESTRUCTURING, ODIOUS DEBT, AND THE POLITICS OF DEBT RELIEF
}

\author{
ROBERT K. RASMUSSEN*
}

\section{INTRODUCTION}

Odious debt is more of a literature than a doctrine. Going back to at least the 1920s, one can find arguments that countries should not have to pay back debts that are labeled "odious." The central intuition is that the citizens of a country should not have to pay for the debts incurred by a prior "odious" regime when those funds did not benefit these citizens. It is simply not right to ask people to pay for funds from which they did not benefit, especially when the lender knew of this fact when it made its loan. The doctrine traditionally has an ex post flavor to it. The question is whether the acts of the past are such that we should relieve a country of what would otherwise be a current obligation. The guiding intuition is moral rather than economic. ${ }^{2}$

In addition to this retrospective view, the doctrine today is also supported by the observation that it may deprive odious regimes of access to funds and hence hasten their demise. The goal of those who support a robust odious debt doctrine is to inhibit lending for projects that do not benefit the people. Lenders would know at the time they make the loan that they face a serious likelihood of having their debt repudiated before it is repaid. ${ }^{3}$ The threat of repudiation

\section{Copyright $(92007$ by Robert K. Rasmussen.}

This Article is also available at http://www.law.duke.edu/journals/lcp.

* Dean and Carl Mason Franklin Chair in Law, University of Southern California Gould School of Law. I would like to thank Mitu Gulati for inviting me to this conference, for his encouragement in considering the general problems associated with sovereign debt, and for his comments on a previous draft of this article. I would also like to thank Anna Gelpern for her comments on a previous draft.

1. The classic definition of "odious debt" is attributed to Sack's 1927 work. See ALEXANDER NAHUM SACK, LES EFFETS DES TRANSFORMATIONS DES ÉTATS SUR LEURS DETTES PUBLIQUES ET AUTRES OBLIGATIONS FinANCIÈRES (1927). Claims relating to the exact date go back at least to 1898, when the United States argued that Cuba's debts to Spain should not be repaid.

2. See, e.g., Noreen Hertz, Why We Must Defuse the Debt Threat, 24 ConTRIB. Pol. ECON. 123, 125 (2005) ("We must demand, as a first principle of debt relief, that loans made to illegitimate regimes... should not have to be repaid by the grandchildren and great-grandchildren of those originally oppressed and pillaged.").

3. The strength of this argument turns on the ability of the odious sovereign to repay before it is ousted. A robust doctrine of odious debt, unless accompanied by some mechanism to recover payments made on such debt, would create incentives to shorten maturities on the debt. Shorter maturities may increase the pain felt by the citizens, at least in the short run, as the despotic regime devotes a larger percentage of its revenues to service its debt. 
would prevent the loan from being made in the first instance. Because the odious regime would thus have its access to capital constricted, it might become more difficult for the disreputable regime to remain in power. Whereas the motivations remain largely moral in nature-that is, to hasten the end of a repressive regime-the argument is economic to the extent that it relies on the incentive effects created by the doctrine. ${ }^{4}$

These arguments, whatever their merits, have found little purchase in actual practice. Despite calls both today and in the past for eliminating debts based on the nature of the debt itself, there have been few cases in which a nation has secured relief on these grounds. ${ }^{5}$ Even those inclined toward a robust vision of international law can point to no treaty or customary practice that would justify describing the odious debt doctrine as an actual part of international law. The doctrine is more aspirational than operational. The current work in the field thus truly seems to be merely an academic exercise.

The recent (and still ongoing) experience of Iraq reveals both the doctrine's allure and its impotency. After the U.S.-led invasion, the new Iraqi government found itself in dire financial straits. Estimates of the country's long-term debt exceeded $\$ 120$ billion. $^{6}$ All realized that the new Iraq regime could never repay such an amount. ${ }^{7}$ Moreover, the less debt relief that the country was able to secure, the more financial strain would be put on what many hoped would be a fledging democracy. Iraq has many pressing needs, and the more funds that the government has to send out of the country, the more difficult it becomes to even hope for broad-based citizen support for the extant leaders.

The attraction of the odious debt doctrine in this situation is readily apparent. The United States and its allies did not want the new Iraqi government saddled with its existing debt burden. Moreover, no one contested the view that Saddam Hussein was a tyrant who spent extravagantly on himself and his confidants while most of the country's citizens struggled. The doctrine seemed to provide a way to "legally" justify eliminating debts while condemning the prior regime. (Unfortunately, there was a bit of a technical problem in that much of Iraq's debt was incurred for what appears to have been

4. For an argument that the incentive effects are more mixed than the standard account, see Albert H. Choi \& Eric A. Posner, A Critique of the Odious Debt Doctrine, 70 LAW \& CONTEMP. PROBS. 33 (Summer 2007).

5. For more fulsome reviews of the history of odious debt, see James Feinerman, Odious Debt, Old and New: The Legal Intellectual History of an Idea, 70 LAW \& CONTEMP. PROBS. 193 (Autumn 2007); Tai-Heng Cheng, Renegotiating the Odious Debt Doctrine, 70 LAW \& ConTEMP. Probs. 7 (Summer 2007).

6. See Martin A. Weiss, Cong. Research Serv., Iraq: Debt Relief 1 (2005), available at http://fpc.state.gov/documents/organization/44019.pdf ("Iraq's public debt was estimated to be U.S. $\$ 120.2$ in nominal value as of the end of 2004.").

7. See JOHN B. TAYlor, Global FinANCIAL WARriors 265 (2007) (reporting that Iraq had debts of about $\$ 121$ billion and GDP of about $\$ 25$ billion annually). 
legitimate purposes; Saddam's lavish expenditures-especially those after the first Gulf War-were funded by oil revenues and not loans. $)^{8}$

The calls for using the odious debt doctrine to relieve Iraq's financial distress have led to a renewed focus on odious debt, in both the public and scholarly arenas. ${ }^{9}$ There are serious ongoing attempts to create a usable odious debt doctrine..$^{10}$ Although the various proposals differ in important respects, they share the same goal. They seek to flesh out the rather obvious problems with the odious debt doctrine as it has been articulated to date. These include defining which regimes are odious, identifying which debts should be within the doctrine's scope, calculating how much relief should be granted, and ensuring that non-odious regimes do not find their access to the financial markets constrained.

In this discussion, the relationship between the doctrine of odious debt on the one hand and sovereign-debt restructuring on the other has been undertheorized. Standing alongside the literature on odious debts is work that attempts to formulate the optimal regime for restructuring a sovereign's debt when the sovereign is in financial distress. Whereas the proposals range from endorsing the current ad hoc approach ${ }^{11}$ to the creation of a full-blown sovereign-bankruptcy regime, ${ }^{12}$ they share the goal of providing a system whereby an indebted nation can pare back its debt to sustainable levels.

The relationship between the calls for a vibrant odious debt doctrine and a framework for restructuring sovereign debt has not been fully settled. For some, the odious debt seems to act as an imperfect substitute for the lack of a more general restructuring regime..$^{13}$ For others, the two are distinct, and loans to a prosperous but repressive country could be void..$^{14}$ What reach the odious debt doctrine should have depends on how one resolves this question.

Regardless of the relationship between odious debt and sovereign-debt restructuring, one theme permeates both literatures. The impulse seems to be to create a "law" here in the sense of a set of rules with a modicum of predictable

8. See Jonathan Stanford, Cong. Research Serv., Iraq's Economy: Past, Present, FUTURE C-53 (June 2003), available at http://export.gov/iraq/pdf/crs_iraq_economy.pdf. The problem created by the doctrine's linkage of debt and expenditure is that money is fungible. Money borrowed for necessary projects could free up internal funds that could then be used to engage in repressive activities. It is for this reason that Patrick Bolton and David Skeel argue that the focus needs to be on odious regimes rather than odious debts. See Patrick Bolton \& David Skeel, Odious Debts or Odious Regimes?, 70 LAW \& CONTEMP. PROBS. 83 (Autumn 2007).

9. See, e.g., Joseph Stiglitz, "Odious Debts," 292 AtLantic MonThly 4, 42 (Nov. 2003); Michael Kremer \& Seema Jayachandran, Odious Debt (Nat'l Bureau of Econ. Research, Working Paper No. W8953, 2002).

10. See, e.g., Lee C. Buchheit, et al., The Odious Debts of an Odious Regime: Piercing the Government Veil, 56 DUKE L.J. 1201 (2007).

11. See, e.g., William W. Bratton \& Mitu Gulati, Sovereign Debt Restructuring and the Best Interest of Creditors, 57 VAND. L. REV. 1 (2004).

12. See, e.g., Steven L. Schwarcz, Sovereign Debt Restructuring: A Bankruptcy Reorganization Approach, 85 CORNELl L. REV. 956 (2000).

13. See, e.g., Stiglitz, supra note 9.

14. See, e.g., Bolton \& Skeel, supra note 8 . 
results. ${ }^{15}$ One factor that seems to play little role in any of the proposals is the political importance of the country seeking relief to the interests of those-both public and private-that have lent the money at issue. The various reconceptualizations of the doctrine that have been put forth would be available to all countries. No special break is offered to countries that the world powers view as strategically important. Iraq and Sudan would stand on the same footing. Indeed, for those who view international law as distinct from realpolitick, this universal availability can be viewed as a praiseworthy feature of these efforts.

The history of the debt relief in Iraq, however, provides something of a cautionary note. In the end, Iraq has received debt relief, but it expressly eschewed relying on the odious debt doctrine. ${ }^{16}$ It did not seek to walk away from its past debts based on the nature of the Saddam government. Part of the reason seems to be the instincts of the private lenders. They can accede to political pressure and treat it as a one-off event. Acknowledging the doctrine of odious debt, on the other hand, exposes them to an uncertain risk. Once a precedent is created, it is unclear when it will be applied next. ${ }^{17}$ Indeed, the recent calls of Ecuador and Norway to repudiate illegitimate debt provide vivid examples of the private lenders' concerns.

The political imperative-especially on the part of the U.S. and British administrations, who had staked so much on the war effort-was such that Iraq was able to strike a deal reducing a substantial portion of its debt. ${ }^{18}$ Its remaining obligations were rescheduled, with payments to start in the future. The new government was thus provided a breathing space, at least from its foreign-debt woes. The unavoidable fact is that it is the strategic importance of Iraq and not the impulses behind the odious debt doctrine that is responsible for the reduction that the country has achieved in its external debt.

Iraq is by no means unique in this regard. One does not have to look hard to see that political concerns often loom large when a country is seeking relief from its external debt. ${ }^{19}$ Yet this is not necessarily a cause for concern. Some legal academics contributing to the emerging literature on both odious debt and sovereign-debt restructuring generally have done important work in bankruptcy

15. Most in this area would be content to end up in a system where, according to Henkin's legendary observation, "most states follow most of the rules most of the time."

16. Iraq's finance minister stated,

Iraq's need for very substantial debt relief derives from the economic realities facing a postconflict country that has endured decades of financial corruption and mismanagement under the Saddam regime. Principles of public international law such as the odious debt doctrine, whatever their legal vitality, are not the reason why Iraq is seeking this relief.

Interview by Felix Salmon with Adil Abdul Mahdi, Interim Iraqi Finance Minister, quoted in Anna Gelpern, What Iraq and Argentina Might Learn from Each Other, 6 CHI. J. INT'L L. 391, 406 (2005).

17. See Taylor, supra note 7 , at 255.

18. See id. at 250-73 (describing the negotiations that led to the debt reduction agreement).

19. See id. at 252 ("Many of the debt deals that the Paris Club handles involve a combustible mixture of a raw international politics and rocket science financial engineering."). 
literature..$^{20}$ In that literature, it is an article of faith for many that the government should not pick winners and losers. By and large, most endorse the proposition that the ultimate success of a company has to come through competition. Attempts to save various businesses have received much scorn. The bankruptcy of Eastern Airlines remains as an example quickly deployed to remind all that good intentions do not make a competitive company.

It is not clear that this instinct should be transported to the world of sovereign debt. To be sure, one can make a general case for some minimal level of relief. Just as individuals deserve a fresh start, so may countries. ${ }^{21}$ Yet beyond that, it may be that additional debt relief should be left to the political process. Indeed, there is a tension here. To the extent that one views the questions of sovereign debt relief as questions of finance-that is, maximizing a state's access to credit by relieving the debt overhang-one will endorse different policies than if one views the sovereign market as one that involves political dimensions as well. ${ }^{22}$

\section{II}

\section{SOVEREIGN-DEBT RESTRUCTURING AND ODIOUS DEBTS}

The academic scholarship surrounding issues of sovereign debt has exploded over the last few years. ${ }^{23}$ This renewed interest on the part of the academy can be traced to two events. ${ }^{24}$ The first is the proposal by Anne Krueger, First Deputy Managing Director of the International Monetary Fund (IMF), to create a sovereign-debt-restructuring mechanism. ${ }^{25}$ The IMF endorsed the creation of such an institution, but the United States declined to support it. The U.S. government instead put its weight behind amending the terms of the public bonds that a country issues so that they could be restructured through the

20. Scholars writing in both fields include Mechele Dickerson, Adam Feibelman, Steven Schwarcz, and David Skeel.

21. See Robert K. Rasmussen, Integrating a Theory of the State Into Sovereign Debt Restructuring, 53 Emory L.J. 1159, 1179 (2004) (comparing discharge of sovereign debt with the "fresh start" individual debtors may receive under U.S. bankruptcy law).

22. Anna Gelpern's contribution to this conference recognizes this tension. She articulates the ways in which government lending are political and not economically driven, and suggests that in distress situations government debts receive a lower priority. See Anna Gelpern, Odious, Not Debt, 70 LAW \& CONTEMP. PROBS. 81 (Summer 2007).

23. An extensive list can be found in Adam Feibelman, Equitable Subordination, Fraudulent Transfer, and Sovereign Debt, 70 LAW \& CONTEMP. PROBS. 171 (Autumn 2007).

24. This is in addition to the tireless efforts of Mitu Gulati and Lee Buccheit to interest a diverse range of scholars in this important topic.

25. See Daniel K. Tarullo, Neither Order Nor Chaos: The Legal Structure of Sovereign Debt Workouts, 53 EMORY L.J. 657, 673-77 (2004). To be sure, important work on sovereign debt predates the default of Argentina. See, e.g., Kunibert Raffer, Applying Chapter 9 Insolvency to International Debts: An Economically Efficient Solution with a Human Face, 18 WORLD DEV. 301 (1990). Indeed, sovereign debt restructuring became a topic of concern after the Asian financial crisis in the 1990s. Yet, it seems to be that Krueger's proposal sparked a new round of debate. See, e.g., Conference on Sovereign Debt Restructuring: The View from the Legal Academy, 53 EMORY L.J. (Special Issue) 657 (2004); Lee C. Buchheit, A Quarter Century of Sovereign Debt Management: An Overview, 35 GEO. J. INT'L L. 37 (2004). 
collective action of the bondholders. ${ }^{26}$ Whether it was the tepid reception by the United States, the ability of Argentina to procure debt relief through its own hardball tactics, or a lack of interest by those who lend to sovereigns, it seems to be the case that there is little current push in policy circles for a legal framework designed to address the problems that arise when a country cannot repay its debts. While the creation of a general sovereign-debt-restructuring mechanism is currently off the table, academics have furthered our thinking on what features such a regime should contain. When policy makers return to sovereigndebt restructuring, they will have a broad array of choices.

The second event which has drawn attention to issues of sovereign debt is the invasion of Iraq and the establishment of a new government there. The doctrine of odious debt was pulled out of the closet and dusted off as people looked for a way to address the financial problems that Iraq faced post-Saddam Hussein. Odious debt is in some ways more limited and in some ways more broad than the general sovereign-debt restructuring that was the focus of policymakers only a few years ago. It is more limited in that only certain loans fall within the doctrine's purview. The regime has to be "odious" and the loans have to be issued with the lender understanding that the proceeds would not benefit the nation's citizens..$^{27}$ It is broader in that, for loans that are deemed odious, they are eliminated rather than reduced. ${ }^{28}$ Whereas the various sovereign-debt restructuring mechanisms that have been proposed seek to pare down debt to sustainable levels, the odious debt doctrine does not focus on overall debt loads. It is the nature of the debt rather than the amount of the burden that determines whether relief will be granted.

With substantial progress having been made on paring down Iraq's debt, calls for an aggressive application of the doctrine of odious debt have faded from policy circles. Even though the process of putting Iraq's financial affairs in order is by no means complete, it seems safe to say that the odious debt doctrine has had no impact on the process. ${ }^{29}$ Recent actions by Ecuador suggest that it may attempt to rely on some version of the odious debt doctrine as it attempts to reduce its outstanding debt obligations, but it is far from clear that such arguments will find a receptive audience.

Academics, recognizing the underdeveloped state of the doctrine, are currently creating a better doctrine. Each aspect of the doctrine is being subjected to rigorous scrutiny, and new, more complete versions are being

26. See Taylor, supra note 7, at 110-32. For an argument that such amendments are insufficient to solve the sovereign-debt problem because they do not address the problem of interbond negotiations, see David A. Skeel, Can Majority Voting Provisions Do it All?, 52 EMORY L.J. 417 (2003).

27. Patrick Bolton and David Skeel take issue with this aspect of the traditional doctrine. See Bolton \& Skeel, supra note 8.

28. Some of the proposals in this conference suggest a rethinking of this aspect of the doctrine. See Omri Ben-Shahar \& Mitu Gulati, Partially Odious Debts?, 70 LAW \& CONTEMP. ProBS. 47 (Autumn 2007).

29. See Taylor, supra note 7, at 255 ("While no one disagreed that Saddam was odious, there were economic and political reasons not to employ the argument ...."). 
proposed. To the extent that odious debt again resurfaces as a policy issue, this latest round of work may provide officials with a useful starting place.

The precise relationship between the proposals for restructuring sovereign debt and for creating a workable odious debt doctrine remains unclear. At one extreme, the doctrines seem to be substitutes for each other. Many who prefer odious debt seem to do so because the current mechanism for sovereign-debt restructuring does not provide, to their minds, adequate relief. Such a tendency is most evident in the calls to use the doctrine in the case of Iraq. Iraq's debt load provided an impetus for seeking a way to cut back on its obligation, and the claim of odious debt was a means to that end.

For those having such an instinct, the first, best world would be one in which there was a generous system of sovereign-debt relief. Distressed countries could repair to the system and have their debt trimmed substantially. Were such a regime in place, there would be no work for the odious debt doctrine to perform. All countries would be entitled to the same baseline of relief. Absent such a system, however, expansive use of the doctrine could provide at least partial relief.

Others seem to take the opposite approach. For them, odious debt is conceptually distinct from sovereign-debt restructuring..$^{30}$ Even the most affluent country could annul debts that were incurred by a prior, odious regime. Even were the world to embrace an optimal sovereign-debt restructuring regime, this would leave the scope of the odious debt doctrine untouched. Patrick Bolton and David Skeel adhere to this view of odious debt. ${ }^{31}$ Their proposal to have the United Nations Security Council label a regime as odious has nothing to do with relieving financial distress. To be sure, they acknowledge that the number of regimes likely to be tagged with this label is quite small. But since they are not relying on this mechanism to address the general problem of sovereign indebtedness, ${ }^{32}$ this is not a telling criticism. They quite rightly respond that, measured solely by the criteria of creating incentives to undermine repressive regimes, their proposal is a step in the right direction.

One can also imagine a third possible relationship between sovereign-debt restructuring and odious debt. Sovereign-debt-restructuring proposals in the

30. The domestic analogy in the United States is the doctrine of equitable subordination. The doctrine stands apart from the question of how much a debtor's obligations should be paid back and instead penalizes a creditor for its inequitable conduct. Indeed, Adam Feibelman argues that equitable subordination could be applied in the sovereign debt context. See Feibelman, supra note 23.

31. Bolton and Skeel would focus on odious regimes rather than odious debts. See Bolton \& Skeel, supra note 8. This focus comes from the work that they want the doctrine to do-undermine repressive regimes. To spare the reader, however, this article uses the term "odious debt" to refer to all proposals in this genre, even if the focus is on the regime rather than the debt.

32. Bolton and Skeel have elsewhere proposed a mechanism to address the general problem of sovereign debt. See Patrick Bolton \& David A. Skeel, Jr., Inside the Black Box: How Should a Sovereign Bankruptcy Framework Be Structured?, 53 EMORY L.J. 763, 780-801 (2004) [hereinafter Bolton \& Skeel, Inside the Black Box] (setting forth sovereign bankruptcy proposal); Patrick Bolton \& David A. Skeel, Jr., Redesigning the International Lender of Last Resort, 6 CHI. J. INT'L L. 177, 179 (2005) [hereinafter Bolton \& Skeel, Lender of Last Resort] (proposing a new and ambitious crisis lending role for the International Monetary Fund). 
main seek to reduce debt to "sustainable" levels. What is sustainable, however, is a contentious issue. The question depends in large measure on what one views as the appropriate sacrifices a nation's citizens should be asked to bear in order to service the country's debt. The more money that one believes should be invested in the country's economic development, the less will be available to pay foreign creditors.

In deciding how much of a burden should remain on a country's citizens, the nature of the past debt may play a role. One may be inclined to ask citizens to shoulder more repayment for money that was invested in the country. Paying back money used to enhance infrastructure may be more sustainable than paying back money that has been sent overseas to the private accounts of a country's leaders. In this respect, there are obvious parallels to American bankruptcy law. As Mechele Dickerson points out, U.S. bankruptcy law is both committed to a fresh start for individual debtors and calibrates the extent of the fresh start based on the nature of the past debts. ${ }^{33}$ Although there are obvious differences-U.S. law tends to exempt morally problematic debts from discharge whereas incorporating the odious debt doctrine into a sovereign-debt framework would do the opposite-the intuition is the same. The extent of relief from past debts should depend in part on the nature of the debt.

The goal here is not to defend any of the possible relationships between sovereign-debt restructuring and odious debt. Indeed, it is unclear whether one conception must necessarily dominate the others. Rather, the point is that how one approaches odious debt depends on how one views its interaction with sovereign-debt restructuring. The more one seeks to use the doctrine to relieve burdensome debts, the broader its scope. Conversely, the more one focuses on the nature of the old regime, the narrower the doctrine becomes. Differences in proposals turn in part on what one is trying to achieve.

\section{III}

\section{THE IMPULSE TO MOVE FROM POLITICS TO LAW}

Despite competing views on the relationship between odious debt and sovereign-debt restructuring, most work in both areas shares a common theme. The proponents of new systems to address the problems of odious debt and sovereign-debt restructuring seek to move the availability of past-debt relief from the realm of politics to that of law. Both seek to establish criteria that would guide and constrain attempts at debt relief. Political considerations, to the extent that they are unavoidable, need to be cabined. A country's ability to reduce its debt should not depend on who its friends are. 
Indeed, some of the proposals expressly seek to lessen, if not remove, political influence. ${ }^{34}$ For example, in proposing a sovereign-debt-restructuring mechanism, Patrick Bolton and David Skeel argue that it should be administered by existing corporate bankruptcy courts. ${ }^{35}$ One reason they would not put such a mechanism inside the IMF is that "IMF decisionmaking has in some instances been driven more by political pressures by the United States or other G-7 members than by the economics of the crisis in question." ${ }^{, 36}$ Similarly, in arguing for a more precise and more effective vision of the doctrine of odious debts, Christoph Paulus remarks that "[b]ecause of well-known reservations, this responsibility should not be accorded to the IMF/World Bank ...." ${ }^{37}$ Relief from debt should turn on the fiscal state of the country or the nature of the debt itself and not on the extent to which the country seeking relief is able to curry favor with those nations that can exercise influence.

Whereas the desire to remove political influences is rarely defended, it seems to stem from at least two instincts. The first is a general instinct toward equal treatment. Lawyers, perhaps by virtue of their legal training, tend to value equal treatment toward those they view as similarly situated. ${ }^{38}$ Many lawyers recoil at suggestions that law and politics are the same. Moreover, while they may recognize that favoritism exists in the application of law, most would regard this as a problem. We do not celebrate the speeder whose connections allow him to escape the ticket he deserved.

The second impulse toward equality may be that many approach the problems surrounding sovereign debt from a background in U.S. bankruptcy law. Of the authors contributing to this symposium, Mechele Dickerson, Adam Feibelman, Caroline Gentil, and David Skeel come from that tradition. ${ }^{39}$ One important strand of thought in bankruptcy scholarship is that insolvency systems should be designed so as to minimize a debtor's cost of credit. ${ }^{40}$ Part of this work also stresses that, in doing so, bankruptcy courts should not attempt to

34. See Lee C. Buchheit, The Role of the Official Sector in Sovereign Debt Workouts, 6 CHI. J. INT'L L. 333, 343 (2005) ("One way of explaining the S[overeign] D[ebt] R[estructuring] M[odel] proposal is to view it as an effort to establish a rule-based framework for processing sovereign debt workouts with a minimum of official sector interference."); Stiglitz, supra note 9, at 42 ("We need an international 'bankruptcy' court, with no vested national interest, to deal with debt restructuring and relief ....").

35. See Bolton \& Skeel, Inside the Black Box, supra note 32, at 809-18.

36. Id. at 810 .

37. Christoph G. Paulus, “Odious Debts” vs. Debt Trap: A Realistic Help?, 31 Brook. J. InT'L L. 83, 101 (2005).

38. Another possible explanation would be that those people with a strong sense of equality are more likely to attend law school. Or it may be, contrary to my sense of casual empiricism, that lawyers are no bigger fans of equality than is the general populace.

39. One can readily identify others whose primary interest is American bankruptcy law and who have weighed in on the issues of odious debt and sovereign debt restructuring. See, e.g., Steven L. Schwarcz, "Idiot's Guide” to Sovereign Debt Restructuring, 53 EMORY L.J. 1189 (2004).

40. See, e.g., Robert K. Rasmussen, Debtor's Choice: A Menu Approach to Corporate Bankruptcy, 71 TEX. L. REV. 51, 56-65 (1992); Alan Schwarcz, A Normative Theory of Business Bankruptcy, 91 VA. L. REV. 1199 (2005). 
pick winners and losers. ${ }^{41}$ The ultimate fate of the business is left to the marketplace. All that bankruptcy can do is increase a company's chances to the extent that it can increase the debtor's access to funds and lower its cost of credit. Bankruptcy law, on this account, can only create mischief when it tries to advance a political agenda.

This is not to say that a background in bankruptcy law means that one will take the same approach to the problems of odious debt and sovereign-debt restructuring. A vibrant doctrine of odious debt seeks to reduce the amount of such debt in the first instance. The aspirations of at least some backers of the doctrine are that it will cool the ardor of lenders seeking to lend money to certain regimes. The goal here is to decrease debt capacity in the hopes that a country's future will not be squandered on the follies of the present, corrupt regime.

The argument works in the other direction in the sovereign-debt literature. A substantial amount of work in that area addresses the effect of the ability to restructure sovereign debt on a county's incentives to pay the debt, which in turn affect its ability to obtain financing in the first instance. The basic intuitions here come straight from corporate finance. By setting the rules at the optimal level, we can increase a country's debt capacity.

Despite these differing effects on a nation's ability to borrow money, proposals to restructure debt according to bankruptcy rules by and large seek to put more law and less politics into the process.

\section{IV \\ THE INVEVITABILITY AND DESIRABILITY OF POLITICS IN SOVEREIGN DEBT RELIEF (ODIOUS OR OTHERWISE)}

Politics nonetheless seems to be everpresent in sovereign-debt workouts. The United States came to the rescue of Mexico because it seemed to be in the best interests of the United States to do so. The United States discharged the small debt that it was owed by Iraq. Moreover, the Bush Administration charged one of its most trusted political allies, James Baker, with crafting a solution to the Iraq debt problem. America and Europe attempted to pressure Argentina to seek a more modest debt restructuring than it desired. Moreover, to the extent lending is often the province of sovereigns rather than syndicates, ${ }^{42}$ we would expect that political concerns would play an even larger role in all debt relief discussions.

41. See Robert K. Rasmussen, An Essay on Optimal Bankruptcy Rules and Social Justice, 1994 U. ILL. L. REV. 1, 42 ("[G]iven the nature of bankruptcy law, it is hard to see how [bankruptcy law] can work as a mechanism to remedy any existing unjustified inequality in the distribution of primary goods."); Alan Schwarcz, A Contract Theory Approach to Business Bankruptcy, 107 YALE L.J. 1807, 1816-20 (arguing that bankruptcy law should "function only to reduce the costs to firms of debt finance."); Schwarcz, supra note 39, at 1211-12; David A. Skeel, Jr., Giant Bailouts are Becoming a Misguided U.S. Cure-All, L.A. TIMES, Sept. 24, 2001, § 2, at 9.

42. On the rise of sovereign lenders, see Gelpern, supra note 22. 
Such political influence is not surprising. Powerful governments seek to promote their interests abroad. Indeed, most citizens want their government to pursue such an agenda. Humanitarian concerns are part of the agenda for most countries. Both current indebtedness and past ill treatment can induce a country to use its influence in pursuing debt relief. It is nevertheless the case that such concerns are not the only reasons why rich countries seek debt relief for poor ones. The harm that a distressed country can inflict on a rich country's interests is an important part of the calculus over how much effort a rich country will devote towards securing debt relief for a poor one.

To be sure, the fact that a country seeks to further its own interests in international affairs does not doom the general project of international law. Laws can work to the benefit of all countries. ${ }^{43}$ Yet it has to be the case that for international law to develop in any particular area, the countries involved have to see a benefit in reducing and channeling their discretion. One cannot reasonably expect that countries will sign onto any system of international debt relief that they view as counter to their long-term interests. They will agree to cabin their political interests only if such an agreement itself furthers the ends of the state.

In this light, it may be some time before we see international consensus emerge on either a sovereign-debt-restructuring mechanism or a useable doctrine of odious debt. ${ }^{44}$ Consider the United States. It is difficult to imagine the adoption of either an odious debt doctrine or sovereign-debt restructuring system without America's active support. The United States, however, has a variety of potential interests when it confronts another country that has been the victim of a brutal regime or that is currently mired in financial distress. The United States may be a lender to such country, it may have banks that lent to the country, ${ }^{45}$ and its global-political agenda may be affected by such a country. It is fairly obvious that how these differing (and competing) interests balance out will differ across time and across countries. Under the current regime, the United States can balance its financial interests (including those of its citizens) against its political interests when faced with financial distress of any given country. ${ }^{46}$ It is difficult to see how it would be in the United States' interest to give up this ability to balance ex post.

Although the doctrine of odious debt could in theory provide the United States with some lever to attempt to oust an odious regime, it is unclear how

43. For an attempt to explain why countries find it in their interests to follow international law, see Andrew T. Guzman, International Law: A Compliance Based Theory, 90 CAL. L. REV. 1823 (2002).

44. One can find little political support for revamping the current debt restructuring regime, either through the implementation of a sovereign debt restructuring mechanism or a doctrine of odious debt that actually provides debt relief.

45. See Thomas Oatley \& Jason Yackee, American Interests and IMF Lending, 41 INT'L PoL. 415 (2004) (showing that higher levels of U.S. bank debt are associated with more generous lending by the IMF).

46. As Anna Gelpern points out, a country's initial decision to make a loan tends to be driven more by political concerns than the expectation of financial reward. See Gelpern, supra note 22. 
much this innovation would add to its toolbox. The United States already has a number of tools at its disposal, including economic sanctions and military force. It is far from clear that the odious debt doctrine would provide any marginal improvement in its ability to destabilize odious regimes. If anything, the doctrine could be more trouble than it is worth. The United States may well shy away from creating a system in which others could label a regime odious and seek to nullify its repayment obligations.

The same analysis applies to other wealthy countries as well. Although they obviously do not share all of the aims of the United States, they have their own competing sets of interests at stake when another country seeks debt relief. Currently, they can evaluate these interests on a case-by-case basis. Proposals for a new odious debt doctrine and for sovereign-debt restructuring would have to promise them a better outcome across a range of cases. Moreover, the proposals would have to be in the individual interests of each country that could effectively block its implementation. Crafting regimes that satisfy these participation constraints is a daunting task.

Of course, those advocating changes in sovereign-debt restructuring and the doctrine of odious debts have pointed out numerous advantages to their approaches. There are many proposals that may indeed be more normatively desirable than the current system. What these advocates have failed to do so far is to demonstrate to lending nations that it would be in their interest to give up the political clout they currently have when a country seeks debt relief. Political reality thus suggests that the more ambitious attempts to inject law-like predictability into the present debt relief system have little chance of adoption. ${ }^{47}$

More provocatively, it may be that political considerations can play a positive role in this area. Rather then crafting regimes to avoid political influence, we should endeavor to find systems that harness it. To be sure, it is easy to conjure up ideal sovereign-debt-restructuring systems and a perfect odious debt doctrine. But in reality, we would expect them to fall short. Even if countries agree to a system that ostensibly limits their power, they will seek ways to influence the outcome. ${ }^{48}$

To see the possibility for improvement, consider a system that guarantees a minimal level of relief to countries. This relief could be based on either the amount of debt the country has or the nature of the debt. The point is, rather than seek an optimal level of debt forgiveness, we should create a system that automatically grants relief on terms that all countries can agree to before the fact. ${ }^{49}$ (The Bolton-Skeel proposal may be an example of such a system in the

47. This is not to imply that these efforts are either worthless or misguided. Understanding what the ideal system would look like can help us better understand the system we currently have and the extent to which it falls short.

48. I am by no means the first to make this observation. See, e.g., Daniel K. Tarullo, Rules, Discretion, and Authority in International Financial Reform, 4 J. Int'l Econ. L. 613, 639-40 (2001).

49. One does not necessarily have to worry about private lenders here. What they desire most is predictability so that they can price the credit they are extending. 
area of odious debt.) The less that countries have to commit to initially, the more likely it is that they would be willing to give their consent. All would understand, however, that such a system would be a floor rather than a ceiling. Rich countries that found it in their interests to lobby for additional debt relief on a case-by-case basis would be free to do so.

It would be generous to label the above suggestion even a "sketch" of a method for addressing issues of sovereign debt. A sustained effort to build such a system has to wait for another day. Crafting sovereign-debt regimes is difficult. In the commercial context, we rely on the assumption that all lenders by and large want to make money. Lenders use the levers of control available to them in order to maximize their financial return. In the sovereign context, the blend of commercial interests and political ones presents a daunting challenge. Governments have different levers of control than do private creditors. Moreover, in some situations governments will at least consider their financial interests, while in others the political interests will dominate. Going forward, we should strive to craft systems that do not seek to eliminate political interests but rather allow them to build upon the minimal debt relief on which all can agree in advance.

\section{$\mathrm{V}$ \\ CONCLUSION}

Odious debt and sovereign-debt restructuring are neither inextricably linked nor inevitability distinct. The problems of debt overhang and corrupt regimes can be tackled either simultaneously or separately. Regardless of the strategy that one adopts, one cannot ask for too much from the system. Debt relief in this context is and will be as much a matter of statecraft as it is of financial theory. Rather than fight this fact, we need to embrace it. Modest relief as a matter of right coupled with more generous relief as a matter of self-interest may lead to more overall debt relief than would otherwise be available. 